\title{
VASI Questionnaire in the context of Brazilian Secondary Education: an Analysis of the Students' Understanding of Scientific Inquiry
}

\section{O Questionário VASI no contexto do Ensino Fundamental II Brasileiro: uma Análise do Entendimento de Estudantes acerca da Investigação Científica}

\author{
iD Mariana A. Bologna Soares de Andrade ${ }^{1}$ \\ Norman G. Lederman² \\ Judith Lederman ${ }^{2}$
}

\begin{abstract}
'Universidade Estadual de Londrina (UEL), Centro de Ciências Biológicas, Departamento de Biologia Geral, Londrina, PR, Brasil. Autora Correspondente: marianaandrade@uel.br

${ }^{2}$ Illinois Institute of Technology, Chicago, Illinois, USA.
\end{abstract}

\begin{abstract}
Science education researchers agree that a better understanding of Scientific Inquiry (SI) is one of the main objectives of Scientific Literacy. Considering the Brazilian scenario in which $\mathrm{SI}$ is being implemented as a proposal for science education based on Base Nacional Comum Curricular (BNCC), the aim of this study was to assess the notions of 169 elementary school students regarding SI by administering the VASI questionnaire. This study had a qualitative approach, we categorized the answers in Naïve, Mixed and Informed according to the 8 aspects of SI proposed on the original questionnaire. A low percentage of answers were classified as Mixed or Informed. The results corroborate to the argument that activities that prioritize the doing inquiry do not necessarily lead the students knowing inquiry. We consider that the VASI questionnaire can be applied by teachers now that different curricula based on investigation are been adopted in Brazil.
\end{abstract}

Keywords: Scientific inquiry; VASI questionnaire; Inquiry activities.

Resumo: Pesquisadores em Ensino de Ciências concordam que um melhor entendimento da investigação científica (IC) é um dos principais objetivos da literacia científica. Considerando o cenário brasileiro, no qual o IC vem sendo implementado como proposta para a educação científica baseada na Base Nacional Comum Curricular, o objetivo deste estudo foi avaliar as noções de 169 alunos do Ensino Fundamental II acerca da IC por meio do questionário VASI. Este trabalho teve uma abordagem qualitativa, e categorizamos as respostas em Ingênuo, Misto e Informado, de acordo com os oito aspectos da IC proposto no questionário inicial. Uma baixa porcentagem das respostas foi considerada como Misto ou Informado. Os resultados corroboram com o argumento de que atividades que priorizam o fazer investigativo não necessariamente levam os estudantes a conhecer a IC. Consideramos que o questionário VASI pode ser aplicado por professores, já que diferentes currículos baseados em investigação estão sendo adotados no Brasil.

Palavras-chave: Investigação científica; Questionário VASI; Atividades investigativas.

Recebido em: $30 / 06 / 2020$

Aprovado em: 20/10/2020 


\section{Introduction}

Currently, science education researchers agree that a better understanding of Scientific Inquiry (SI) is one of the main objectives of Scientific Literacy (ABD-EL-KHALICK, 2014; ABD-EL-KHALICK, LEDERMAN, 2000; ALCHIN, 2013; CRAWFORD, 2014; LEDERMAN; LEDERMAN, 2014). Another importance of SI is that students need to know about inquiry so they can make informed decisions with respect to scientific claims (LEDERMAN, 1999). According to Schwartz (2004), SI is related to specific aspects of the development of scientific knowledge, including the conventions for its acceptance and utility.

Part of the construction of the scientific literacy promoted in schools - i.e. practices that can contribute to promote literacy in the citizenship and the students became autonomous and independent thinkers that are able of answering relevant issues (ROBERTS, 2008) - involves different aspects and practices, and two of them are doing inquiry and knowing inquiry. Even though they are intrinsically related it is often assumed that students who do inquiry will necessarily develop understandings about inquiry (LEDERMAN et al., 2019).

Research on science education indicates the articulation between the educational practices of science and the abilities for scientific processes. That relationship is grounded in scientific investigations. Different objectives can be ascribed to educational practices because they prepare future scientists and contribute to a better understanding of the methods, contents, and principles of science (DEBOER, 2006).

Concerning with that notion, there are in the literature indications that inquiry activities may also bring students closer to how scientific knowledge is produced. This approximation favors access to the practices of scientific culture, linked to cultural, historical, social, political, and economic features. It is enabling a better understanding of scientific inquiry and therefore may affect students' scientific literacy (DEBOER, 2006; FERRAZ; SASSERON, 2017; GRANDY; DUSCHL, 2007; SASSERON, 2015; SEDANO; CARVALHO, 2017; TRIVELATO; TONIDANDEL, 2015).

However, Lederman et al. (2019) explain that there is an intuitive misconception that knowing about SI is linked with the doing of SI specially because part of the researches emphasized the doing of inquiry, which oftentimes is assumed to imply an understanding of inquiry.

SI in science teaching is evidenced directly in pedagogical proposals that adopt research as models of teaching and learning. Quoting the National Research Council (NRC) and The Next Generation Science Standards (NGSS), Crawford (2014) discusses that teaching science as inquiry involves using critical thinking skills, which include "[...] asking questions, designing and carrying out investigations, interpreting data as evidence, creating arguments, building models, communicating findings in the pursuit of deepening their understanding by using logic and evidence" (CRAWFORD, 2014) ${ }^{1}$. The author also suggests that, inspired by this perspective, it is possible to identify different educational proposals, such as project-based learning, problem-based learning, scientific initiation, research among citizens, and model-based research.

1Abstract retrieved on Oct. 232020 from: https://cutt.ly/1 gbzcLW. 
In Brazil, for decades, researches have discussed the practices involving SI, and the significance of understanding the meaning of investigative work. In this report, we present some of the results of Brazilian investigations related to SI from the last decades.

According to Galiazzi et al. (2001), research work can be summarized as a multicyclic process with three components, namely, the question, the construction of the arguments, and the validation of the results. Critical dialogues inside the group mediate all three components. On the other hand, Trivelato and Tonidandel (2015) emphasize that students should develop or improve their proficiency in observing, manipulating laboratory subjects, reflecting, discussing, explaining, and reporting. Those skills are closely related to scientific practices and scientific investigations.

As stated by Zômpero e Laburú (2011), students are engaged in developing cognitive abilities. They also formulate hypotheses, take notes and analyze data, and develop argumentation skills. From investigative activities, they can develop cognitive abilities, such as observing, registering data, comparing, perceiving pieces of evidence, inferring, drawing conclusions, improving the rationale, and arguing.

To Sedano and Carvalho (2017), the Investigation Teaching offers students the opportunity to search for a solution to a problem. In small groups, they formulate and test hypotheses, then they communicate, argue, question, and discuss the stages and their decision-making processes. In doing so, they experience scientific culture practices, which have their own rules, values, and languages.

Since the 1990s, the Parâmetros Curriculares Nacionais (PCN), or National Curricular Parameters (BRASIL, 1996), guide the school curricula in Brazil. The document refers to secondary education and does not discuss the development of SI practices, contrary to Brazilian researches. The only reference to that level of teaching is that it should be a preparation for secondary education. The secondary education's PCN (BRASIL, 1999) suggests involving the development of practical, contextualized knowledge that responds to contemporary life's necessities, and the development of more ample and abstract knowledge, which corresponds to general culture and a world view (BRASIL, 1999).

The document also stresses the need for articulating practical and critical learning and its relationship with scientific culture. Therefore, different parts of the construction of scientific knowledge must guide science teaching. However, research and scientific investigation practices didn't appear explicitly on the documents' text, and there was little governmental encouragement to perform changes in the teachers' practices.

In 2018, a new guidance document for Basic Education was published, called Base Nacional Curricular Comum (BNCC), or National Common Curricular Basis (BRASIL, 2018). It is more emphatic in its proposition of educational practices involving $\mathrm{SI}$, especially throughout the secondary education stage. According to the BNCC, the investigative approach must promote the students' protagonism in their learning, and also in the application of processes, practices, and procedures that produce technological knowledge. During this stage of schooling, open and contextualized challenges and problems must trigger this approach, and the search for solutions of theoretical and experimental nature stimulates curiosity and creativity (BRASIL, 2018). Such as observation is also evident when the document claims that "[...] the specific competencies and abilities proposed to explore problem situations that involve improvements in quality of life, security, sustainability, ethnic and cultural diversity, among others" (BRASIL, 2018, p. 550, our translation). 
BNCC proposes the learning of Natural Sciences, throughout all basic education, through a scientific inquiry that includes:

(1) Define problems, it involves observing the world and asking questions, analyzing demands, outlining issues, planning investigations, and proposing hypotheses;

(2) Carry out surveys, analyses, and representations, the students can prepare and perform field activities, develop and use tools for gathering, analyzing, and representing data. It is also related to evaluating information, formulating explanations or models, associating explanations, selecting and constructing arguments, and developing solutions to everyday problems;

(3) To communicate, communication involves organizing and exploring conclusions, reporting information in different media, presenting data in a systematic form, participating in scientific discussions, and considering counter-arguments to review findings;

(4) Interventions, to do so, the student should apply solutions and evaluate their effectiveness to solve everyday problems, and develop actions to improve the individual, collective, and socio-environmental quality of life (BRASIL, 2018).

According to Sasseron (2018), SI was one of the structure-building elements for BNCC's Natural Sciences curricula but had little effect on the promotion of this approach. Compared to BNCC, studies within this research area have been more effective. BNCC's proposal can also be challenging for schools and teachers, due to two factors: (1) it was published a short time ago, and (2) the document's implications and its consequences to basic education are still unknown. This problem occurs because BNCC involves several aspects beyond the investigative proposal. Nevertheless, both public and private schools in Brazil have developed initiatives for students to construct knowledge about and within science through investigation.

Brazilian researches and document curriculum guide prioritize the doing of SI and some pedagogical approaches but not the taught of SI explicitly which means an approach that uses instruction geared toward various aspects of SI and utilizes elements from the history and philosophy of science to improve learners' views of the SI (LEDERMAN, 1999).

Understanding SI ideas can contribute to improving teachers' practices and for students to perceive the role of science in their lives. Lederman et al. $(2013,2019)$ indicate that there are few researches that have assessed students' knowledge of SI, so the authors have proposed a questionnaire to assess students in basic education.

Considering the Brazilian scenario in which $\mathrm{SI}$ is being implemented as a proposal for science education and the importance of SI for scientific literacy in this study we aim to evaluate the notions of elementary school students regarding scientific inquiry by administering the VASI questionnaire proposed by Lederman at al. (2013).

\section{The Theoretical Proposal of VASI Questionnaire}

In 2013, Professors Judith and Norman Lederman and their group of research studies published the paper Meaningful assessment of learners' understandings about scientific inquiry: the views about scientific inquiry (VASI) questionnaire (LEDERMAN et al., 2013). The group presented the elaboration, development, and analysis of an open questionnaire with seven questions to assess the students' understanding of SI. 
The authors list eight aspects that basic education students should develop about SI, elaborated by the reformulation of previous data collection instruments and new theoretical studies:

1. All scientific investigations begin with a question and do not necessarily test a hypothesis. According to the authors, scientific work is more than a simple observation of the living world; it consists of formulating and answering questions.

2. There is no single scientific method. Scientists understand that there is a variety of available methodologies; they use different types of investigation based on the question they need to answer.

3. Inquiry procedures are guided by the question asked. Students need to understand the necessary alignment between the research question and method. Moreover, they must be aware that the question governs the approach and that the method of investigation must be suitable for answering the question.

4. The same procedures may not exhibit the same results. The interpretation of data can occur in different manners, even if the researchers ask the same questions and follow the same procedures. This difference might exist partially due "[...] to a scientist's theoretical framework, what he or she considers as evidence, and how anomalous data are handled" (LEDERMAN et al., 2013, p. 69).

5. Procedures can influence results. This point is grounded in the idea that "[...] the operationalization of variables, the methods of data collection, and how variables are measured and analyzed all influence the conclusions reached by researcher" (LEDERMAN et al., 2013, p. 69). Based on NGSS, the authors indicate that the students "[...] should develop an understanding of the logical connection between the method of inquiry, the specific procedure therein, the data collected, and thus the conclusion drawn" (LEDERMAN et al., 2013, p. 70).

6. Conclusions must be consistent with the data collected. For the authors, "[...] students need to understand that the strength of a scientist's claim is a function of the preponderance of the evidence that supports it. The validity of the claims is further strengthened by the alignment of the research method with the research question" (LEDERMAN et al., 2013, p. 70).

7. Scientific data are not the same as scientific evidence. Data and evidence have different purposes in an investigation. Data are "observations gathered by the scientist in the course of the investigation" (LEDERMAN et al., 2013, p. 70). They appear in different formats, such as numbers, photographs, and physical samples. On the other hand, the evidence is "a product of data analysis procedures and subsequent interpretation and is directly tied to a specific question and a related claim".

8. Explanations are based on a combination of collected data and previous knowledge. Students need to understand the relationship between already established scientific knowledge and conclusions derived from empirical data and new analyses. 
Even though the eight aspects presented by the authors are not explicit on the BNCC we think that there is a relationship between them and what is presented on the document, which reveals a possible way to articulate activities that involve the doing and knowing inquiry. Therefore, the questionnaire could be a way to assess student's understanding about SI.

The group led by Judith and Norman Lederman uses the VASI questionnaire to evaluate how secondary school students in different countries understand scientific inquiry (LEDERMAN et al., 2019). The results presented in this report refer to the data collected in Brazil.

\section{Methodology}

This study had a quantitative approach, and the instrument of data collection was the VASI questionnaire (LEDERMAN et al., 2013). To the development of the Brazilian stage, we translated the questionnaire into Portuguese (Portuguese version is attached), and then back into English, to check for distortions or errors. After the questionnaire translation was validated, we started to conduct the study. The questionnaire was answered by 169 students from five schools in the city of Londrina, Parana State, Brazil.

The sample selection began with the students' grades; all of them were in the seventh grade at secondary school II. We chose schools with different curriculum profiles, from ones that prioritize scientific investigation $(n=3)$ to ones where there is no activity related to it $(n=2)$. We also included public and private schools of different economic background. Even though our sample drew from only five institutions, they are very similar to the other ones in urban areas of much of Brazil. This sample does not represent rural schools, indigenous schools, quilombolas communities' schools, or rural settlements' schools.

The data collected were transcribed into typed tables. We identified each student by the letters BS (Brazilian student), followed by cardinal numbers from 01 to 169; for instance, BS-017. We did not aim to analyze schools separately, so they will not be identifiable from the transcriptions.

The VASI aspects/questions were previously evaluated for alignment with an $80 \%$ higher agreement in Lederman et al. (2013). The Brazilian researchers were trained to analyze the VASI - by skype meetings - directedly by the US researchers. For this study a reliability was re-establish with the Brazilian and the US researchers, the inter-rater agreements exceed $80 \%$.

The analysis of the data was carried out by Brazilian and USA researchers, using a holistic approach (LEDERMAN et al., 2013). We categorized the answers according to what was presented by the subject throughout the entire questionnaire. A consistent response, fully congruent with the target response, was marked as Informed. If it was not entirely consistent with the target response, or mildly contradictory, it was marked as Mixed. A contradictory response, or one that was incongruent with the context, it was marked as Naïve. Finally, when there was no answer it was classified as $N / A$ (no answer). Examples of answers for each aspect could be found in Table 1. 


\section{Results and Conclusions}

We organized the results of the questionnaire analyzes according to the eight categories pre-established by Lederman et al. (2013). Each category was related to one or more questions. Data analysis is presented in Table 1.

Table 1 - Learners' understanding of SI, percentages and examples

\begin{tabular}{|c|c|c|c|c|}
\hline Questions & Naïve & Mixed & Informed & N/A \\
\hline $\begin{array}{l}\text { All scientific investi- } \\
\text { gations begin with } \\
\text { a question and do } \\
\text { not necessarily test } \\
\text { a hypothesis } \\
\text { Q. } 02\end{array}$ & $\begin{array}{l}74,5 \% \\
\text { BS-0135: I agree with who answe- } \\
\text { red 'no' because they don't neces- } \\
\text { sarily need a scientific question, } \\
\text { you can simply start with a ques- } \\
\text { tion from everyday questions. }\end{array}$ & $\begin{array}{l}6,5 \% \\
\text { BS-076: I agree with the one who } \\
\text { said yes because if an investigation } \\
\text { got no objective, it would be lost, or } \\
\text { do not have an answer, the question } \\
\text { is like a goal. }\end{array}$ & $\begin{array}{l}1,9 \% \\
\text { BS-057: I agree with the first } \\
\text { student (yes) because to start an } \\
\text { investigation you need a problem } \\
\text { to solve. }\end{array}$ & $17,1 \%$ \\
\hline $\begin{array}{l}\text { There is no single } \\
\text { scientific method } \\
\text { Q. } 01\end{array}$ & $\begin{array}{l}74,3 \% \\
\text { c- BS-132: No, because they } \\
\text { have their own laboratory, and } \\
\text { everyone always has the same } \\
\text { thing.. }\end{array}$ & $\begin{array}{l}10,9 \% \\
\text { C- BS-014: Yes, this investigation } \\
\text { of the birds and the investigation } \\
\text { of how the world began. In every } \\
\text { survey, they used different methods } \\
\text { to come to a conclusion so they can } \\
\text { be considered scientific. }\end{array}$ & $\begin{array}{l}0,6 \% \\
\text { c- BS-077: Scientific investigation } \\
\text { can be conducted by various me- } \\
\text { thods, such as observation, ques- } \\
\text { tionnaires, surveys, searches, and } \\
\text { practices. }\end{array}$ & $14,2 \%$ \\
\hline $\begin{array}{l}\text { Inquiry procedures } \\
\text { are guided by the } \\
\text { question asked } \\
\text { Q. } 05\end{array}$ & $\begin{array}{l}83,2 \% \\
\text { BS-016: Team B tested a single } \\
\text { brand to see if it was tough, as } \\
\text { team A are encouraged to test } \\
\text { any tire into a single road. Team } \\
\text { A is motivated by a single goal } \\
\text { while the others are motivated } \\
\text { in various tire brands. }\end{array}$ & $\begin{array}{l}11,2 \% \\
\text { BS-003: Team A is right because } \\
\text { they really have the one road and } \\
\text { there are several brands of tires, not } \\
\text { many are actually able to flat. Team } \\
B \text { has three roads, but in fact, they } \\
\text { need only one road. }\end{array}$ & $\begin{array}{l}\text { 1,9\% } \\
\text { BS-077: The procedure of team } \\
\text { A was better because they tested } \\
\text { various tracks, and the B team } \\
\text { tested a mark on different types } \\
\text { of roads, and the goal was to see } \\
\text { the strength of the brands. }\end{array}$ & $3,7 \%$ \\
\hline $\begin{array}{l}\text { Same procedures } \\
\text { may not exhibit the } \\
\text { same results } \\
\text { Q. } 03 \text { a }\end{array}$ & $\begin{array}{l}82,8 \% \\
\text { BBS-007: Yes, because they think } \\
\text { the same way, and BS-167: Yes, } \\
\text { because they are scientists, as } \\
\text { they are scientists, they know } \\
\text { everything in science. }\end{array}$ & $\begin{array}{l}\text { 9,5\% } \\
\text { BS-124: No, because the methods } \\
\text { can be the same, but each one can } \\
\text { discover something different. Even } \\
\text { though all the same, some may } \\
\text { suffer change when performing } \\
\text { an experiment, leading to an error } \\
\text { of percentage. }\end{array}$ & - & $7,7 \%$ \\
\hline $\begin{array}{l}\text { Procedures can } \\
\text { influence the results } \\
Q .03 \mathrm{~b}\end{array}$ & $\begin{array}{l}81,1 \% \\
\text { BS018: Because no matter if they } \\
\text { follow different procedures, what } \\
\text { matters is the initial question. }\end{array}$ & $\begin{array}{l}6,5 \% \\
\text { BS-010: Maybe, because a scientist } \\
\text { can follow a method and get a } \\
\text { result, and the other may follow } \\
\text { different methods and comes to } \\
\text { the same result. }\end{array}$ & $\begin{array}{l}0,6 \% \\
\text { BS036: They don't need to come } \\
\text { to the same result as some } \\
\text { experiments may give different } \\
\text { evidence. }\end{array}$ & $11,8 \%$ \\
\hline $\begin{array}{l}\text { Conclusions must be } \\
\text { consistent with data } \\
\text { collected } \\
\text { Q. } 06\end{array}$ & $\begin{array}{l}68 \% \\
\text { BD-003: (alternative a) The plants } \\
\text { actually grow with more sunlight, } \\
\text { but water also helps them grow, } \\
\text { so both are needed. }\end{array}$ & $\begin{array}{l}17,1 \% \\
\text { BS-032: (alternative b) Because } \\
\text { according to the table, I drew this } \\
\text { conclusion. }\end{array}$ & $\begin{array}{l}0,6 \% \\
\text { BS-131: (alternative b) Because } \\
\text { the table shows that with less } \\
\text { sunlight the flower grows more. }\end{array}$ & $14,3 \%$ \\
\hline $\begin{array}{l}\text { Data does not equal } \\
\text { evidence } \\
\text { Q. } 04\end{array}$ & $\begin{array}{l}75,7 \% \\
\text { BS-006: Data is something recor- } \\
\text { ded, i.e., we are sure it exists, and } \\
\text { evidence is suspicious, i.e., we are } \\
\text { not sure it exists. }\end{array}$ & $\begin{array}{l}4,7 \% \\
\text { BS-069: Yes, there is a difference. } \\
\text { Example: The data is collected from } \\
\text { someone or something, and with } \\
\text { these data, there is the evidence. }\end{array}$ & $\begin{array}{l}0,6 \% \\
\text { BS-073: Data is the person col- } \\
\text { lecting the information (data) to } \\
\text { have some conclusion. Evidence, } \\
\text { it is with this data you end up with } \\
\text { evidence, that's the difference. }\end{array}$ & $19 \%$ \\
\hline $\begin{array}{l}\text { Explanations are } \\
\text { developed from } \\
\text { data and previous } \\
\text { knowledge } \\
\text { Q. } 07\end{array}$ & $\begin{array}{l}66,3 \% \\
\text { BS-131: (a) Because the femur is } \\
\text { in the leg not in the arms, and if } \\
\text { it were so, it would be deformed; } \\
\text { (b) By doing research. }\end{array}$ & $\begin{array}{l}7,7 \% \\
\text { BS-011: (a) Because their bones are } \\
\text { in the right place, and there are no } \\
\text { errors in his arms, nor in the legs; (b) } \\
\text { Many scientists use dinosaur fossils } \\
\text { to reach their conclusions. }\end{array}$ & $\begin{array}{l}0,6 \% \\
\text { BS-057: (a) The position of the } \\
\text { bones can assist in animal loco- } \\
\text { motion, food capture, defense } \\
\text { etc.; (b) They research the bones, } \\
\text { other fossils, while others research } \\
\text { the life of the dinosaurs etc. }\end{array}$ & $25,4 \%$ \\
\hline Total & $75,7 \%$ & $9,3 \%$ & $0,9 \%$ & $14,1 \%$ \\
\hline
\end{tabular}

Source: prepared by the authors. 
Question number 2 in the VASI questionnaire was proposed to analyze the aspect that all scientific investigations begin with a question and do not necessarily test a hypothesis. The question was: two students are asked if scientific investigations must always begin with a scientific question. One of the students says 'yes' while the other says 'no'. Whom do you agree with and why?

Several answers were classified as Naïve $(74,5 \%)$ because the students chose one of the options without presenting any justification. Nevertheless, among the justified answers, there were mistakes on what makes a question scientific, so they might not understand that routine problems can have a scientific basis. On the other hand, the students that presented Mixed (6,5\%) and Informed (1,9\%) answers understood the problem as the starting point of the investigation.

Our analysis showed that the students' obstacle was to understand that any problem can be scientific - as long as it is a problem that needs to follow specific procedures to be solved. Procedures include surveys and analysis of theoretically based data to achieve an answer that can be considered scientific. School activities that prioritize the resolution of problems and problematizations can help students understand the role of the question and the operations to search for answers.

Question number 1 was proposed to analyze the aspect there is no single scientific method. The question presented was: a person interested in birds looked at hundreds of different types of birds who eat different types of food. He noticed that birds who eat similar types of food, tended to have similar shaped beaks. For example, birds that eat hard-shelled nuts have short, strong beaks, and birds that eat insects have long, slim beaks. He wondered if the shape of a bird's beak was related to the type of food the bird eats and he began to collect data to answer that question. He concluded that there is a relationship between beak shape and the type of food birds eat. (A) Do you consider this person's investigation to be scientific? Please explain why or why not. (B) Do you consider this person's investigation to be an experiment? Please explain why or why not. (C) Do you think that scientific investigations can follow more than one method?

Here, we intended to identify how students perceive the different paths that a scientific investigation can follow evidenced by the letter C. $74,3 \%$ of the answers were classified as Naïve.

On item C, many of the unjustified Naïve answers were that a scientific investigation follows one single method or more than one method. The justified answers evidenced some conceptual obstacles to the students. For instance, they saw the differences between a scientific and a criminal investigation as reasons for the different methods.

All answers classified as Mixed (10,9\%) were that there is more than one method and were justified by examples from researches. On the other hand, Informed answers $(0,6 \%)$ indicated the existence of different methods and offered examples of different paths for an investigation.

Importantly, the general analysis of all the answers indicated that the students link scientific investigation directly to experimentation. That mistake was present in their answers on the three topics, so it is crucial to differentiate the two concepts. We note that different knowledge and research areas can change the students' views on research methods and methodology and that change could be achieved through investigative activities that require different procedures to reach an outcome. 
Within the third aspect, we sought to identify if students understand that inquiry procedures are guided by the question asked. For that, we used the answers to question 5 which was: two teams of scientists were walking to their lab one day and they saw a car pulled over with a flat tire. They all wondered, 'Are certain brands of tires more likely to get a flat?'. Team A went back to the lab and tested various tires' performance on one type of road surface. Team B went back to the lab and tested one tire brand on three types of road surfaces. Explain why one team's procedure is better than the other one.

There was a rate of $83,2 \%$ of Naïve answers. The majority of Naïve answers could not connect the presented question to the choice of the best procedure, but there was a significant difference between the answers. Part of them considered both to be good as long as they were complementary. Alternatively, they approved of them as long as they were reasonable. In other answers, both were considered inadequate because they were incomplete.

Additionally, some students chose one of the two teams. The ones that chose team $B$ justified that it was correct because its procedures are related to the different tracks. Part of the students who chose team A were marked as Naïve because there was no indication that their choice was connected to the question - but to the analysis of the two processes. There was also a group that did not relate the procedures to the question. Within that group, some explanations were based on the differences between the procedures, although they could not choose the best team, because each one studied different aspects.

Students who gave Mixed answers $(11,2 \%)$ considered that team A presented the best procedures. Nevertheless, their justifications did not address the guiding question. Even though they understood the question, it was still not possible to identify a direct relationship between the question and the method to be adopted.

The students classified as Informed $(1,9 \%)$ claimed that team $A$ had the best procedure because they were searching for a specific answer to the question.

From these responses, it is clear that the students could not understand what was being asked and the related method. The analysis of the Naïve answers shows that understanding this issue involves: (a) seeing the question is a guide for the election of the procedure; (b) the question should be a guide for understanding the procedures; and (c) the question is crucial to delimit the aspects or factors related to the research operations.

Students' answers classified as Mixed or Informed were based on the postulated situation ("how to identify which tire brand is easier to get flat".) For this, it is reasonable to propose activities to identify research questions and seek ways to solve them. Moreover, students should be enabled to formulate their own research questions.

Question 3a - If several scientists ask the same question and follow the same procedures to collect data, will they necessarily come to the same conclusions? Explain why or why not was proposed to identify the aspect same procedures may not exhibit the same results in the students' answers.

This aspect presented one of the most substantial number of Naïve answers $(82,8 \%)$. According to their answers, the same question and the same procedure make researchers think alike. Moreover, part of the answers was that, following the same procedures, researchers would always reach the same conclusion. Finally, they considered that all researchers thought the same way, as they were scientists. 
Students who gave Mixed answers (9,5\%) considered that the results would not necessarily be the same. They also pointed out what could influence the results, such as the differences in the data collected and the different ways of thinking. Another resultaffecting factor mentioned was the development of similar procedures that suffered alterations or errors. None of the answers were categorized as Informed.

Although research work is characterized as objective, it suffers many interferences. However, according to our analysis, students did not notice that. The Naïve answers show stereotyped ideas - all scientists think alike; all procedures lead to the same conclusion.

Some Mixed answers presented factors that might affect conclusions, like an error. However, even considering the influence of isolated factors, they did not see the possibility of many aspects interfering in the results. It reveals a technicist approach of science, which needs to be overcome through educational activities that show that different factors can affect scientific research. Some activities may help to build up a view of science as a field of human construction, through the knowledge of the inner workings of the scientific field and a Science, Technology, Society, and Environment (STSE) education.

The same method might lead to different results. Likewise, the same question and different methods might also lead to different results. The aspect procedures can influence the results reflects the idea that any given procedure invariably affects the outcome. Question 3b - If several scientists ask the same question and follow different procedures to collect data, will they necessarily come to the same conclusions? Explain why or why not was proposed for this matter, and students were expected to answer that different conclusions could be drawn due to the different procedures and results obtained.

A significant part of the answers $(81,1 \%)$ was considered Naïve for different reasons. Some students stated that what mattered in an investigation was the initial question. Others, that scientific thinking is the same for all researchers, and that researchers would get to the same results, no matter the procedures. The ones marked as Informed were exact and on point.

The students did not understand the role of the results presented by different methodological procedures in a scientific investigation. They linked result-affecting factors to the researcher, not to the evidence generated by different procedures. Investigative activities in which different groups of students perform the same procedures might engender reflections on the issue like we can see on the Informed answer.

To investigate the aspect that Research conclusions must be consistent with data collected, question 6 was proposed: the data table below shows the relationship between plant growth in a week and the number of minutes of light received each day.

Table 2 - Table presented in question 6 of VASI questionnaire

\begin{tabular}{|c|c|}
\hline Minutes of light each day & Plant growth-height (cm per week) \\
\hline 0 & 25 \\
\hline 5 & 20 \\
\hline 10 & 15 \\
\hline 15 & 5 \\
\hline 20 & 10 \\
\hline 25 & 0 \\
\hline
\end{tabular}

Source: prepared by the authors. 
Given this data, explain which one of the following conclusions you agree with and why. Please circle one: (a) Plants grow taller with more sunlight. (b) Plants grow taller with less sunlight. (c) The growth of plants is unrelated to sunlight.

Since the presented indicates a relationship that is reverse proportional and indicates a trend, the students were expected to choose alternative $B$.

The Naïve answers (68\%) can be divided in (1) students who chose wrong answers based on correct concepts about photosynthesis, not present on the table; (2) students who could not interpret the table; and (3) students who justified their answers with the wrong concepts of photosynthesis and the plants' growth.

All Mixed answers $(17,1 \%)$ pointed to alternative B. In this category, justifications indicated that the students correctly interpreted the table. In the Informed category $(0,65 \%)$, the students chose alternative B and demonstrated their analysis of the table.

We noted an intriguing obstacle for students to overcome: the knowledge presented cannot be considered as absolute truth. It is necessary to develop a critical view of science as more than the accumulation of information. For this matter, activities in which students analyze scientific controversies may be helpful. We also propose activities in which they could question aspects of science themselves.

We explored the aspect scientific data are not the same as scientific evidence through Question 4: Please explain if 'data' and 'evidence' are different from one another.

Clearly, students have difficulties in understanding what evidence is, $75,7 \%$ of the answers were considered Naïve. The vast majority do not differentiate data from evidence, and their answers were full of mistakes about what each one really is. For instance, that data are factual, and evidence is unreliable. Another mistake stems from the dichotomy between scientific and criminal investigation. The latter is known from TV series and news media. In those answers, data are more related to scientific investigations, and evidence of criminal investigations.

Despite distinguishing between data and evidence, the Mixed answers (4,7\%) still did not characterize evidence as a product of data analysis. Only one student had an Informed answer to this question.

Our analysis showed that the students had an antagonistic idea of data and evidence. Data and evidence were considered as concrete/non-concrete, truthful/to be proven, correct/suspicious. The relationship between them was not manifested. Most importantly, we found that the influence exerted by the news media impacted the students' conceptions of criminal investigations. Data would be an aspect of SI and evidence a proof of criminal investigations. Their most significant difficulty was related to what a piece of evidence is. In this instance, we propose investigative activities in which students establish what their work's data are and what the emerged evidence is. That should be done by developing their research using analyses.

Question 7 was proposed considering the aspect that Explanations are developed from data and previous knowledge: the fossilized bones of a dinosaur have been found by a group of scientists. Two different arrangements for the skeleton are developed as shown below. 
Figure 1 - Figures presented in question 7

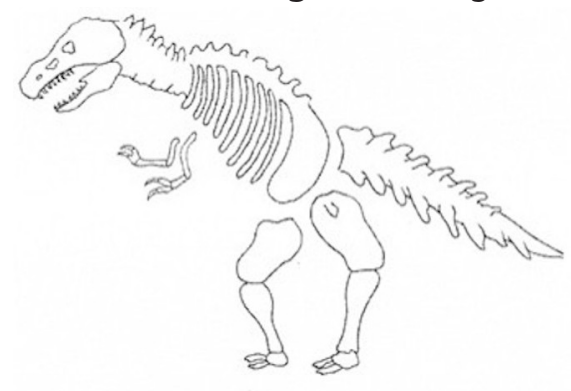

Fig. $1 \mathrm{a}$

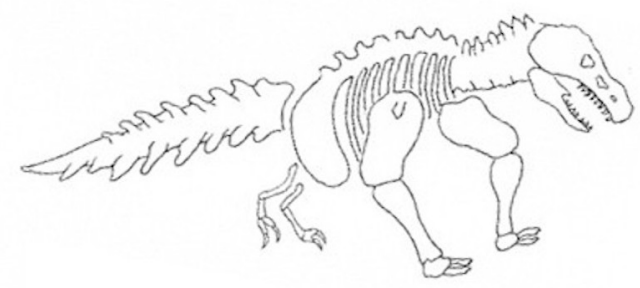

Fig. $1 \mathrm{~b}$

(a) Describe at least two reasons why you think most of the scientists agree that the animal in figure $1 \mathrm{a}$ had the best sorting and positioning of the bones? (b) Thinking about your answer to the question above, what types of information do scientists use to explain their conclusions? The answers for both items were analyzed holistically.

In the Naïve category $(66,3 \%)$, item B represented more difficulty to the students. For item A, some students justified their choice for Dinosaur 1 with anatomical remarks. For others, knowing any species of dinosaur sufficed. They could not perceive that scientifically established knowledge helps comprehension - even when they use that very knowledge to answer item $A$.

In the Mixed answers $(7,7 \%)$, students could use their previous knowledge of anatomy to explain why Dinosaur I was the best. They also indicated that researchers used the knowledge that had already been produced. The Informed answer $(0,6 \%)$ was in line with the assertion of items $A$ and $B$.

Our analysis shows that, even if the students use previous scientific knowledge to draw their conclusions, they cannot pinpoint its source. Observation is still a significant factor for their explanations, and many did not say that previous knowledge of dinosaur anatomy and physiology affected their answers. It would be helpful to engage students in analytic activities of previously developed scientific work. For instance, through investigative works about History and Philosophy of Science.

The suggestions we have made in each aspect are related to the four objectives of the investigation presented by BNCC (BRASIL, 2018). They are (1) definition of problems; (2) surveys, analysis, and representation; (3) communication; and (4) intervention. However, it is important to emphasize that the aspects presented by the BNCC and the aspects proposed to be analyzed by the VASI questionnaire belong to different spheres, while Lederman et al. (2013) indicates aspects regarding Knowing inquiry, the BNCC proposal is based on doing inquiry. Although there is a relationship between them, the doing inquiry will not necessary lead students to knowing SI. We believe that the effective knowledge regarding $\mathrm{SI}$ needs as articulation between doing and knowing inquiry and that is the only possible if the inquiry practices in schools are based in the reflection of what is being developed by students and teachers as pointed by Akindehin (1988, p. 73) "[...] should be planned for instead of being anticipated as a side effect or secondary product" of varying approaches to science teaching. Therefore, teachers and researchers can use this instrument to assess the skills developed by their students. 
As presented in the introduction SI can be adopted in different ways in school, doing SI, pedagogical approaches and teaching aspects of SI. The students who answered the questionnaire were from different schools, and three of them had curricula with SI approaches. These results reflect the situation of the students investigated.

\section{Final Considerations}

In Brazil, decades of research in Science Teaching show the importance of SI for the Basic Education. However, such investigations which tend to prioritize doing inquiry, didn't reflect a significative change in science teaching in secondary or high school curricula. Indeed, changes in the actions and curricular organization in schools are imperative with BNCC's promulgation (which presents a normative character for Basic Education). However, more than were presented in some of the Brazilian Science Education researches, the BNCC proposes that schools develop activities to improve students learning of science by defining problems, carrying out surveys, communicating and interventions. There are no indications related to the reflection of what is being done by the students that will lead them to know aspects of the scientific work and, consequently, allow them to be able to make informed decisions with respect to scientific claims. Therefore, it is critical to propose instruments to evaluate the students' ideas about SI and indicate the relationship between what is recommended by BNCC and possible actions.

This study aimed to analyze the students' conceptions about SI. It was evident that students had little knowledge of SI. A low percentage of answers were classified as Mixed $(9,3 \%)$ or Informed $(0,9 \%)$. Half of the students who answered the VASI questionnaire come from schools which carry out some investigative activities - all of those schools' proposals are based on doing inquiry - and, even so the percentage of Naïve and No Answer (57, 7\% e 14, 11\%, respectively) was very high. The results corroborate to Lederman's argument (LEDERMAN et al., 2013) that activities that prioritize the doing inquiry do not necessarily lead the students knowing inquiry. In Brazil, the practices of teaching for investigation, even if still underdeveloped, are required because of BNCC. Given this demand, the results can be taken into consideration for future work.

Therefore, we consider that the VASI questionnaire can be applied by teachers and schools now that different curricula based on investigation are been adopted in Brazil, especially those who provide activities based on doing and reflecting about inquiry. Such results could bring more evidences to the discussion concerning the SI meaning to science education and scientific literacy.

\section{References}

ABD-EL-KHALICK, F. The evolving landscape related to assessment of nature of science. In: LEDERMAN, N. G.; ABELL, S. K. (ed.). Handbook of research in science education: volume II. New York: Routledge, 2014. p. 621-650.

ABD-EL-KHALICK, F.; LEDERMAN, N. G. Improving science teachers' conceptions of nature of science: a critical review of the literature. International Journal of Science Education, London, $v$. 22, n. 7, p. 665-701, 2000. DOI: https://doi.org/djncjd. 
AKINDEHIN, F. Effect of an instructional package on preservice science teachers' understanding of the nature of science and acquisition of science-related attitudes. Science Education, Hoboken, v. 72, n. 1, p. 73-82, 1988.

ALCHIN, D. Teaching the nature of science: perspectives and resources. Minneapolis: SHIPS Education Press, 2013.

BRASIL. Ministério da Educação. Base nacional comum curricular. Brasília: MEC, 2018. Disponível em: http://basenacionalcomum.mec.gov.br/. Acesso em: 25 out. 2020.

BRASIL. Ministério da Educação. Parâmetros curriculares nacionais para o ensino fundamental: ciências, matemática e suas tecnologia. Brasília: MEC, 1996.

BRASIL. Ministério da Educação. Parâmetros curriculares nacionais para o ensino médio: parte III: ciências da natureza, matemática e suas tecnologias. Brasília: MEC, 1999.

CRAWFORD, B. From inquiry to scientific practices in the science classroom. In: LEDERMAN, N. G.; ABELL, S. K. (ed.). Handbook of research on science education: volume II. London: Routledge, 2014. p. 515-541.

DEBOER, G. E. Historical perspectives on inquiry teaching in schools. In: FLICK, L. B.; LEDERMAN, N. G. (ed.). Scientific inquiry and nature of science: implications for teaching, learning and teacher education. Norwell: Kluwer, 2006. p. 17-35.

FERRAZ, A. T.; SASSERON, L. H. Propósitos epistêmicos para a promoção da argumentação em aulas investigativas. Investigações em Ensino de Ciências, Porto Alegre, v. 22, n. 1, p. 42-60, 2017. DOI: https://doi.org/fgbn.

GALIAZZI, M. C.; ROCHA, J. M. B.; SCHMITZ, L. C.; SOUZA, M. L.; GIESTA, S.; GONÇALVES, F. P. Objetivos das atividades experimentais no ensino médio: a pesquisa coletiva como modo de formação de professores de ciências. Ciência \& Educação, Bauru, v. 7, n. 2, p. 249-263, 2001. DOI: https://doi.org/fxh65s.

GRANDY, R. E.; DUSCHL, R. A. Reconsidering the character and role of inquiry in school science: analysis of a conference. Science \& Education, Switzerland, v. 16, p. 141-166, fev. 2007. DOI: https://doi.org/10.1007/s11191-005-2865-z.

LEDERMAN, J. et al. An international collaborative investigation of beginning seventh grade students' understandings of scientific inquiry: establishing a baseline. Journal of Research in Science Teaching, London, v. 56, n. 4, p. 486-515, 2019. DOI: https://doi.org/10.1002/tea.21512.

LEDERMAN, J. S.; LEDERMAN, N. G.; BARTOS, S. A., BARTELS, S. L.; MEYER, A. A.; SCHWARTZ, R. S. Meaningful assessment of learners' understandings about scientific inquiry: the views about scientific inquiry (VASI) questionnaire. Journal of Research in Science Teaching, Hoboken, v. 51, n. 1, p. 65-83, 2013. Retrieved on Oct. 232020 from: https://onlinelibrary.wiley.com/doi/ abs/10.1002/tea.21512.

LEDERMAN, N. G. The state of science education: subject matter without context. Electronic Journal of Research in Science \& Mathematics Education, Fort Worth, v. 3, n. 2, 1999. Retrieved on Oct. 232020 from https://ejrsme.icrsme.com/article/view/7602.

LEDERMAN, N. G.; LEDERMAN, J. S. Research on teaching and learning of nature of science. In: LEDERMAN, N. G.; ABELL, S. K. (ed.). Handbook of research on science education: volume II. New York: Routledge, 2014. p. 600-620.

ROBERTS, D. A. Scientific literacy/science literacy. In: ABELL, S. K.; LEDERMAN, N. G. (ed.). Handbook of research on science education. Mahwah, NJ: Lawrence Erlbaum, 2008. p 729-780.

SASSERON, L. H. Alfabetização científica, ensino por investigação e argumentação: relações entre ciências da natureza e escola. Ensaio, Belo Horizonte, v. 17, n. especial, p. 49-67, nov. 2015. DOI: http://dx.doi.org/10.1590/1983-2117201517s04. 
SASSERON, L. H. Ensino de ciências por investigação e o desenvolvimento de práticas: uma mirada para a base nacional comum curricular. Revista Brasileira de Pesquisa em Educação em Ciências, Belo Horizonte, v. 18, n. 3, p. 1061-1085, 2018. DOl: https://doi.org/fgfm.

SCHWARTZ, R. S. Epistemological views in authentic science practices: a cross-discipline comparison of scientists' views of nature of science and scientific inquiry. 2004. Thesis (Doctor of Philosophy in Science Education) - Oregon State University, Corvallis, 2004.

SEDANO, L.; CARVALHO, A. M. P. Ensino de ciências por investigação: oportunidades de interação social e sua importância para a construção da autonomia moral. Alexandria, Florianópolis, v. 10, n. 1, p. 199-220, 2017. DOI: https://doi.org/10.5007/1982-5153.2017v10n1p199.

TRIVELATO, S. L. F.; TONIDANDEL, S. M. R. Ensino por investigação: eixos organizadores para sequências de ensino de biologia. Ensaio, Belo Horizonte, v. 17, n. especial, p. 97-114, 2015. DOI: https://doi.org/10.1590/1983-2117201517s06.

ZÔMPERO, A. F.; LABURÚ, C. E. Atividades investigativas no ensino de ciências: aspectos históricos e diferentes abordagens. Ensaio, Belo Horizonte, v. 13, n. 3, p. 67-80, 2011. DOI: https://doi.org/ fgfp.

Attachment A - Visões sobre Investigação Científica²

O questionário a seguir tem perguntas sobre sua visão relacionada à ciência e investigação científica. Não existem respostas certas ou erradas.

Por favor, responda cada uma das seguintes questões. Você pode usar todo o espaço destinado para responder a questão e continuar na parte de trás da folha, se necessário.

1. Uma pessoa interessada em pássaros olhou para centenas de diferentes tipos de pássaros que comem diferentes tipos de comida. A pessoa notou que pássaros que comem alimentos parecidos tendem a ter o formato do bico parecido. Por exemplo, pássaros que comem nozes com casca dura possuem bicos curtos e fortes e pássaros que comem insetos possuem bicos longos e finos. Ele queria saber se o formato do bico dos pássaros estava relacionado ao tipo de comida que eles comiam e começou a coletar informações para responder essa questão. Ele concluiu que existe uma relação entre o formato do bico e o tipo de comida que os pássaros comem.

a. Você considera que a investigação que essa pessoa fez é científica? Por favor, explique sua resposta.

b. Você acha que a investigação que essa pessoa fez é um experimento? Por favor, explique sua resposta.

c. Você acha que a investigação científica pode seguir mais de um método? Se não, por favor, explique porque existe apenas uma maneira de conduzir a investigação científica. Se sim, por favor, descreva duas investigações que seguiram diferentes métodos, explique como os métodos são diferentes e como eles podem ser considerados científicos.

2. Perguntaram para dois estudantes se uma investigação científica deve sempre começar com uma questão científica. Um dos estudantes respondeu 'sim' e o outro respondeu 'não'. Com qual deles você concorda e por quê?

3. (a) Se muitos cientistas têm a mesma questão e seguirem os mesmos procedimentos para coletar dados, eles necessariamente chegarão às mesmas conclusões? Explique o porquê.

(b) Se muitos cientistas têm a mesma questão e seguirem procedimentos diferentes para coletar os dados, eles necessariamente chegarão às mesmas conclusões? Explique o porquê.

${ }^{2}$ Versão em Português traduzida por Mariana A. Bologna Soares de Andrade. 
4. Por favor, explique se existe diferença entre dados e evidências.

5. Duas equipes de cientistas estão caminhando para seus laboratórios e avistam um carro parado com um pneu furado. Eles se perguntam "existem certas marcas de pneus mais prováveis de furar?"

A Equipe $A$ volta para o laboratório e testa várias marcas de pneus em uma única pista. A Equipe B volta para o laboratório e testa uma única marca de pneu em três pistas com superfícies diferentes.

Explique o porquê de o procedimento de uma equipe ser melhor do que o da outra.

6. A tabela de dados abaixo mostra a relação entre o crescimento de uma planta em uma semana e o número de minutos de luz recebido por dia. A partir desses dados, escolha uma alternativa:

\begin{tabular}{|c|c|}
\hline Minutos de sol por dia & Crescimento da planta (cm por semana) \\
\hline 0 & 25 \\
\hline 5 & 20 \\
\hline 10 & 15 \\
\hline 15 & 5 \\
\hline 20 & 10 \\
\hline 25 & 0 \\
\hline
\end{tabular}

Fonte: elaborado pelos autores.

a. Plantas crescem mais com mais luz do sol.

b. Plantas crescem mais com menos luz do sol.

c. O crescimento das plantas não está relacionado com a luz do sol.

Por favor, explique porque você escolheu uma das três alternativas.

7. Os ossos fossilizados de um dinossauro foram encontrados por um grupo de cientistas.

Os ossos do dinossauro foram organizados de duas maneiras diferentes, como mostrado abaixo.

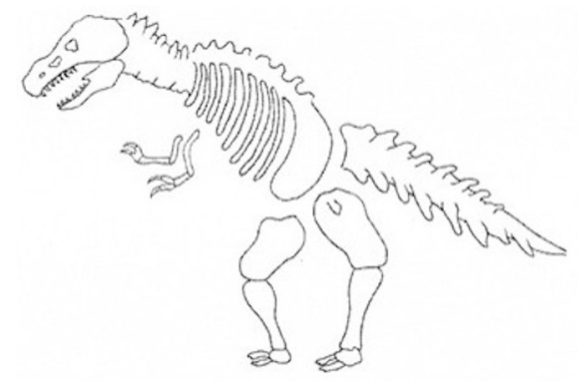

Fig. $1 \mathrm{a}$

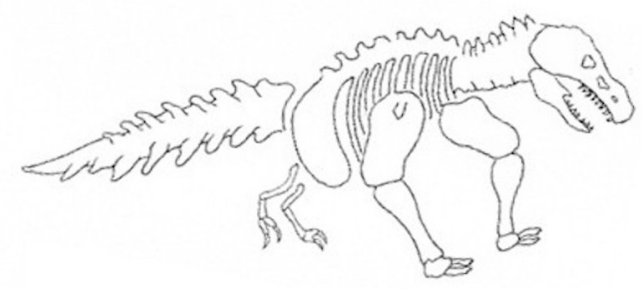

Fig. $1 \mathrm{~b}$

a. Descreva, pelo menos, duas razões por que você acha que a maioria dos cientistas concorda que o animal da figura 1 apresenta o melhor tipo de posicionamento dos ossos?

b. Pensando na resposta que você deu no item anterior, que tipo de informações os cientistas usam para chegar as suas conclusões? 